\title{
Strategic Performance of the Human Resources Management Department: an Exploratory Research on the Implications from the Behavioral Styles of its Professionals
}

\author{
Roberto Coda ${ }^{\dagger}$ \\ Faculdade Campo Limpo Paulista \\ Darly Alcarpe Coda ${ }^{\Omega}$ \\ Editora Abril
}

\begin{abstract}
The objective of this paper is to describe the implications of an exploratory investigation to assess the behavioral preferences of employees in Human Resources Management (HRM) applying the concepts of work motivational orientation (Mediating, Analytical, Receptive and Entrepreneurial) taken from the contributions by Erich Fromm about personality and the resulting styles - Collaborator, Negotiator, Competitor, Conqueror, Achiever, Maintainer and Specialist. These styles originated from a data bank, composing 4,981 cases and the groupings that resulted in the seven profiles utilized in the present work were obtained by multivariate statistical analysis. The survey, relying on self-perceptions of 355 individuals, was obtained through the voluntary participation of employees who work in the HRM Department of the private sector and a public health organization. The results have an impact on the strategic and operational roles that human resources itself performs, since a difference in the composition of the behavioral styles was identified depending on the sector where these professional perform their work.
\end{abstract}

Keywords: Behavioral styles. Motivation. Strategic HRM.

\section{INTRODUCTION}

Received on August 03,2012; reviewed on May 03,2013; accepted on January 13, 2014; published on August 28,2014

*Autor para correspondência:

\footnotetext{
${ }^{\dagger}$ Professor Livre-Docente pela Faculdade de Economia, Administração e Contabilidade da Universidade de São Paulo

Vínculo: Professor Pesquisador da Faculdade Campo Limpo Paulista

Endereço: Rua Dr. Diogo de Faria, São Paulo - SP - Brazil

E-mail: roberto.coda@faccamp.br

Telefone: (11) 5571-4979
}

Nota do Editor: Esse artigo foi aceito por Bruno Funchal

\footnotetext{
$\Omega$ MBA em Recursos Humanos - Faculdade FIA de Administração e Negócios

Vínculo: Consultora de RH - Editora Abril Endereço:

Av. Moreira Guimarães , São Paulo - SP - Brazil

E-mail: darly.coda@abril.com

Telefone: (11) 96372-6363
} 
hroughout history man has been able to gather people and resources together to overcome all sorts of obstacles and reach determined goals. In order for society to produce the goods that individuals need resources considered as production factors must be used: Physical Capital - characterized by the available natural resources such as tools, vehicles, constructions and equipment all used in the process of production; Technology - which will speed up and increase production that guarantees the competitive edge over other economies; Human Capital - characterized by the entire physical and mental effort spent during the production process.

Human capital must be considered a relevant factor for the economic development of any country, without which, there would be no chance of success. This is also valid for the modern organizations of globalization which are constantly becoming more and more competitive in consequence of qualities, competence and, principally, the actions or behaviors of their human capital.

As organizations evolve they become vulnerable to changes in their organizational structure, behavior and the manner in which the employees and collaborators relate with each other. These changes are fundamental because they allow these organizations to adapt to the transformations necessary for market survival.

\subsection{THE ROLE OF THE PROFESSIONAL AND THE HUMAN RESOURCES MANAGEMENT DEPARTMENT}

In the organizational context, the HRM professional can exercise an influential role in organizational life, by defining policies, practices and tools that affect the levels of job satisfaction, motivation, commitment and relationships within the corporate environment and in this way help the organization, as well as individual employees, reach their objectives.

First of all, the changes that have occurred within the environment and the role of HRM on a national and international scale must be considered. As a consequence of the globalization process, this functional area has been under pressure to become more agile, flexible, innovative, and principally, results focused on the specific areas of Recruitment, Selection, Training, Compensation, Careers, Health and Occupational Safety. It is possible to see a change in paradigm in the areas of HRM within organizations, a demand for strategic positioning of the department, a fact which has, in the last few years, caused this area (HRM) to try and define management policies and practices for the human factor based on the concept of professional competences. The challenge facing the area of HRM and its 
professionals is now to identify, map, and evaluate skills within the workforce that are in line with the organization's qualities and proficiencies, collaborating as such, more effectively in reaching the goals established. Therefore, the focus is now a search for a new model of human resources that differs from the traditional approach because it is centered on meritocracy, performance management and the added value this brings to the organization (CODA et al, 2009; DUTRA, 2009; ULRICH, 2009).

It is possible to identify to identify seven themes across time in the HRM literature: (1) explaining contingency perspectives and fit, (2) shifting from a focus on managing people to creating strategic contributions, (3) elaborating HR system components and structure, (4) expanding the scope of SHRM, (5) achieving HR implementation and execution, (6) measuring outcomes of SHRM, and (7) evaluating methodological issues. Each of these themes played a significant role in the evolution of the field (LENGNICK-HALL; ANDRADE; DRAKE, 2009). A national Australian survey indicates that HRM professionals have made the shift to a strategic mindset. In so doing, HRM professionals have marginalized employee-focused HRM responsibilities and ethics activities (VAN BUREN III; GREENWOOD; SHEEHAN, 2011).

Theory and research on strategy and human resource management also point to the importance of human and social capital as essential ingredients to the firm's long run success. Much of the recent research suggests that HRM practices can positively affect firm performance, primarily through their impacts on human and social capital (BULLER; MCEVOY, 2012).These authors stress that the value of the HR function, HR professionals, and HRM practices will ultimately be validated only through their impacts on performance.

Another possibility to assess up to what level HRM can be considered strategic is to test whether basic need satisfaction mediates the relationship between HR practices and HRM outcomes. Research results indicate that autonomy and relatedness satisfaction partially mediate the relationship between HR practices and HRM outcomes. So, HR actors should be aware that merely implementing soft HR practices may not suffice. They should also devote attention towards sufficiently taking into account individual talents, interests and expectations of employees when implementing them (MARESCAUX; DE WINNE; SELS, 2013).

It is also interesting to notice a major trend that seems to appear to assess HRM role in organizations deals with the implications of a whole-systems ecological approach to the design and implementation of human resource systems; being even possible to find and 
explore experiences and case studies on best HR practices to support environmental sustainability in work settings (DUBOIS; DUBOIS, 2012).

Finally, there is also evidence that the perceived effectiveness of the HR department in its operational roles is decisive in trade union representatives' general HR effectiveness assessment. On the other hand, for line managers, process-oriented roles are crucial (DE WINNE, et al., 2013).

These developments are evidence that the course of action taken by the area of HRM within this new paradigm will depend, among others aspects, on the preferred behavioral styles of the HRM professionals, since it is they who should install and lead the proposed changes. However, the courses of action taken will be more visible if the HRM professionals present behavioral styles compatible with the new proposal(s); if they do not, instead of furthering the implementation of the new model, they will represent an obstacle to the process of innovation that HRM must undergo.

In function of the challenges forecast in the theoretical field and the developments considered important and beneficial to the area of HRM, the question that this study proposes to answer is: does this professional have a profile in line with the new model or should he make considerable efforts in personal development?

\section{GENERAL AND SPECIFIC OBJECTIVES}

Within organizational environments identification of behavioral styles and patterns contributes to the recognition of tendencies in the actions taken by professionals that can be used to guide their training, development and placement in the workplace, in this way guaranteeing a balance between natural preferences and necessities or the requirements of the position that is occupied (RICCO, 2004). Using a reference framework designed from the realities of Brazilian organizations for identification of behavioral patterns in actual work situations, the general objective of this work is to identify the Mobilization Styles of the professionals who work in the area of HRM within organizations.

The intended contribution is a mapping of styles and dominant behavioral patterns of professionals who are in the process of establishing their careers in the area of HRM, which can be used to provide support that, will:

- Increase the possibility of and direct changes within the areas of HRM by influencing the actions of the area's professionals and thus take HRM to new heights of efficiency, productivity, quality and service to the organization's employees; 
- Orientate the hiring, keeping and development of these professionals;

- Respect and take into consideration the strong and weak points that are intrinsically associated with the styles which are probably the most representative and thus improve the capacity of these professionals to adapt to the reality of their work or situations;

- Analyze the compatibility between possible dominating styles and the roles and challenges forecast in relevant literature regarding an effective course of action taken by a HRM area.

Therefore, knowing the preferred behavioral style of these professionals using a specific approach to do so (the M.A.R.E. Diagnosis of Motivational Orientations) is one of the aspects with which to evaluate, up to what point, the necessary changes in a course of action by the HRM area has the most possibility to occur in case the results of the research point to a balance and not to a concentration of those styles which will be mapped.

Verifying there is a concentration or the predominance of specific behavioral styles - in this study considered as mobilization styles -, the present work can also contribute to guide the efforts to develop and train the professionals of HRM as well as to hire or promote individuals that possess unusual styles, or rather, styles that favor changes in the role of HRM, thus granting them a more strategic function.

Specifically, this work aims to identify the Mobilization Styles (RICCO, 2004) of professionals that work in the area of HRM, in order to:

a) Identify the possible existence of predominant Mobilization Styles that may configure behavior which is ideal for the adaptation and professional success in the HRM area.

b) Compare the mobilization styles of professionals in the area of HRM that work in private industry with the styles of professionals who work in public service.

Present companies need to meet the challenges of competition, innovation and change, in a context where the human factor can represent a variance which contributes effectively to reaching goals and targets.

Thus, not only the leaders, but the professionals of HRM, too, must understand the organization and translate its mission and objectives to the teams, and also promote the keeping of employees through effective management involving behaviors, relationships, motivation and work commitment. 
It is also an assumption of this work that a self-understanding of the individual styles and motivations of the preferred behavior of HRM professionals can furnish them with a base with which they can exercise their roles in the organization and guide the organization through the established challenges and changes.

\section{THEORETICAL BASIS}

This topic presents and discusses the main concepts that relate to the comprehension and description of the knowledge which forms the basis for carrying out this field research. Basically, concepts covering the individual differences at the job place, motivational theories based on intrinsic variables, a contribution from the works of Erich Fromm, and an interfacing between motivation and leadership are presented. The principal characteristics of the M.A.R.E. motivational guidelines and identified behavioral styles are clearly described (styles of mobilization) insomuch as, these aspects not only represent the theoretical base of the M.A.R.E. Diagnosis of Motivational Orientations but, also provide the basis for the methodology applied in the field research.

\subsection{INDIVIDUAL DIFFERENCES}

Bowditch (1992) stresses that personality is the deciding factor controlling individual differences. Personality refers to relatively consistent and enduring degrees of perception, thought, feeling and behavior which give individuals their unique identity (DAVIDOFF, 2001). In relating the concepts about individual differences to the previously presented motivational theories, one notes that although it is not easy, it is very important that managers and supervisors discover the type and style of the individuals under their supervision so that they can offer them adequate motivational tools and implement effective staffing actions.

Nonetheless, accepting and dealing with the differences in human behavior is not an easy task, although, it is well known that this represents one of the characteristics capable of producing results, just as high levels of productivity and a positive organizational climate that promotes job involvement. It is undeniable that each individual has his own particular way of thinking, preferences, and manner of facing everyday challenges and situations. At present, propositions and necessities are constantly being tested in the workplace due to the continually changing nature of activities. Technologies and managerial philosophies may generate elevated heights of stress that can turn differences in style or guidance into resentments, failures to effectively communicate and interfere with a real understanding of interpersonal intentions. Instead of just simply trying to label people, perception and comprehension of the orientations or motivational preferences of the employees who operate 
within the organizations represent an opportunity to liberate the creative potential of the individuals and oversee the human factor more effectively.

Goleman (2004) states that people are placed in positions of great responsibility without taking into consideration their emotional or interpersonal skills. He defines "emotional skills" or behaviors as how people manage themselves and proposes classifying them into six different categories - self-regulation, motivation, empathy, social skills and the ability to work in groups. For the objectives of this present research project, these categories represent fundamental points of interest since they can be considered traits or the implicit orientations of any manager or professional's profile.

\subsection{MOTIVATION}

Due to the wide range of motivational theories, from the classical such as Maslow's theory of necessities, to the contemporary ones, such as the expectancy of Vroom (ROBBINS, 2010), only those that support this present work by emphasizing the intrinsic aspects of the motivational process, will be exposed.

Whether by common sense or intuitively, each individual has his own conception or idea as to what motivation is, which makes the concept look simple. Nonetheless, the question is quite complex having several theories on the matter with none of them presenting definite answers as how to best motivate people. It is widely understood that motivation is an interior state of mind that causes an individual to follow a determined course of action or behavior (SPÉCTOR, 2002). Motivation is in some way linked to intensity and persistence as it refers to the effort that an individual makes to complete some undertaking and his refusal to give up that course of action. When applying the concept of motivation to work, Robbins (2010, p. 196) defined it as ... "a process responsible for intensity, direction and persistence to reach a specific goal".

Intending to synthesize the concept, Robbins, (2010) proposes the definition of motivation as 'the process which awakens the desire or predisposition to make continuous effort towards achieving some organizational objective, influenced by the organization's capacity to satisfy individual necessities'. The term 'awakens' refers to the impulse or energy that becomes the base of the action. In this sense, the people can be interested in projecting a good image of themselves as a professional in a certain area of work or field of knowledge, perform some task with outstanding quality, have a good feeling about themselves for having performed a certain group of activities, make a lot of money, or experience a feeling of contributing positively to the organization in which they are. Although it should never be 
imagined that these impulses can be the same for different people, that which emerges here as relevant is that there is always one or more reasons that inspire people everywhere or, the concept of motivation has a universal character and helps explain behavior in innumerable situations. So, it is in the interest of the individuals to respond to the motives or impulses that move them and present action which they believe will satisfy the same.

The concept of intrinsic motivation is of special relevance for the objectives of this present work. As will be detailed in the section covering methodology, the identification of behavioral styles begins with a self-perception of preferences or motivational orientations that reveal impulses which are frequently manifest in individual attitudes that are intentional or influenced by situations experienced in a social context.

In light of the concept that motivational orientation represents a preference or internal predisposition to act, the motivational theories which give support to this present work are; those which privilege intrinsic aspects such as the theory of cognitive evaluation (DECI; FLAST, 1998), theories founded on necessities like those of Maslow, Alderfer and McClellan and the presumptions which link motivation at work to feeling or the significance that is given to it by the professional who performs it (CODA; FONSECA, 2004; SIEVERS, 1994).

\subsection{MOTIVATIONAL ORIENTATIONS: CONCEPT AND APPLICATION}

Starting with the fundamental contribution of Maslow, it has been widely recognized that people are motivated by necessities, basically those which are not fully satisfied at any given moment. Although these necessities may be common to all human beings, the manners in which people organize to satisfy them are specific or particular to each individual. Nonetheless, it is still possible to recognize relatively stable tendencies in behavior which characterize what is known as "motivational orientation". By definition, it is any pattern of behavior that surges frequently in the attitudes of someone (FROMM, 1986).

Nevertheless, due to cultural characteristics, it has become necessary to adapt this kind of typology to aspects which can easily be understood by the professional operating within Brazilian companies. Contrary to other approaches, the M.A.R.E. Diagnosis of Motivational Orientations represents an attempt to identify the manifestations of the basic motivational orientations in the workplace instead of just interpreting these motivations using selfperceived personality traits as a base. Consequently, the questionnaire which provides support for conducting this research concentrates on self-perception of customary behavior and action in the workplace, while considering inherent traits of the personality as a secondary theme, underlying the entire process. 
Although there are many ways to utilize the concept of motivational orientation, from the placement of employees in different positions or functional areas (staffing), to the management of culture of an organization, it is worthwhile to investigate some of the specific points where the notion of this concept can be applied. The concept of motivational orientation also permits the evaluation of the preferred conduct during work meetings, adapting the potential of employees to the requirements of one's job, to suggest ways of resolving problems and establish goals, as well as to reduce levels of stress and conflict at work through the comprehension that what motivates and moves one individual may also interfere in the performance of another.

\subsection{ERICH FROMM AND INDIVIDUAL DIFFERENCES}

As an author of psychoanalytical orientation, Fromm gives his contribution by considering the psychoanalytical theory under the light of social psychology of the $20^{\text {th }}$ century which considers man a product of his social environment (RICCO, 2004). In recent studies, Maccoby (2005) considers the contributions of Freud and Fromm quite useful for understanding people and professional/managerial behavior in the workplace, while keeping in view the cultural adaptation of some aspects. Fromm used a Freudian based theory as a system of impulses that serve as a base for behavior. He considers that one should not look for the origin of human behavior in the internal impulses nor in the social pressures, but look in a person who is conscious, have specific necessities and lives within a network of social demands. Within this framework, four principal orientations are identified which reveal individual predispositions classified as: Marketing (M.), Accumulative (A.), Receptive (R.) and Exploitative (E.). The marketing orientation emphasizes the individual's concern with trading, adaptation and integration; the accumulative a focus on synthesis and past experiences the receptive reveals a concern with people and learning and the exploitative reveals a need to take out of the environment all that it offers (FROMM, 1986).

Using the theories that classify individual behavior, measuring devices have been developed that compose what is known as the behavioral diagnosis (RICCO, 2004). One such diagnosis is denominated M.A.R.E. Diagnosis of Motivational Orientations. Here, beginning with the orientations proposed by Fromm (1986), an adaptation of one of these orientations is made for the work environment and the Brazilian reality in an endeavor to develop a valid instrument for measuring these motivational orientations. 


\subsection{THE M.A.R.E. DIAGNOSIS OF MOTIVATIONAL ORIENTATIONS}

The M.A.R.E. Diagnosis is founded in the four orientations proposed by Fromm (1986), adapted by Coda (2000) for situations and behavior within the context of work organizations and renamed as the M.A.R.E. motivational orientations - Mediating, Analytic, Receptive and Entrepreneuring.

Table 1 presents a synthesis of the principal characteristics of each one of these motivational orientations, as well as a view of the parallel established between the classification proposed by Coda (2000), and that originally proposed by Fromm (1986):

\begin{tabular}{|c|c|l|}
\hline FROMM & \multicolumn{1}{|c|}{ CODA } & Characteristics \\
\hline $\begin{array}{l}\text { Marketing } \\
\text { Orientation } \\
\text { (M.) }\end{array}$ & $\begin{array}{l}\text { Mediating } \\
\text { Orientation } \\
\text { (M.) }\end{array}$ & $\begin{array}{l}\text { Focus on relationships. Seeks harmony and integration between } \\
\text { conflicting views in work situations. Comprehends people's } \\
\text { necessities. A talent for selling new ideas. Works well in groups; } \\
\text { sociable and affectionate. }\end{array}$ \\
\hline $\begin{array}{c}\text { Accumulative } \\
\text { Orientation } \\
\text { (A.) }\end{array}$ & $\begin{array}{l}\text { Analytical } \\
\text { Orientation } \\
\text { (A.) }\end{array}$ & $\begin{array}{l}\text { Focus on strategies. Seeks the continuance of actions and processes. } \\
\text { High standards of quality in tasks and procedures. Logical and } \\
\text { rational. Long term view. Indifferent, objective and sincere. Avoids } \\
\text { risks. }\end{array}$ \\
\hline $\begin{array}{l}\text { Receptive } \\
\text { Orientation } \\
\text { (R.) }\end{array}$ & $\begin{array}{l}\text { Receptive } \\
\text { Orientation } \\
\text { (R.) }\end{array}$ & $\begin{array}{l}\text { Focused on people. Develops the teams' skills. Develops own skills } \\
\text { and abilities. Recognizes the value of diversity. A concern with } \\
\text { facilitating things rather than making them more difficult. }\end{array}$ \\
\hline $\begin{array}{c}\text { Exploitative } \\
\text { Orientation }\end{array}$ & $\begin{array}{l}\text { Entrepreneuring } \\
\text { Orientation }\end{array}$ & $\begin{array}{l}\text { Focused on results. Constantly seeks changes and challenges. A } \\
\text { capacity to act and obtain that which is expected. Innovative and } \\
\text { creative. Investigates new markets and business opportunities. }\end{array}$ \\
\hline
\end{tabular}

Table 1 - Principal Characteristics of the M.A.R.E. Motivational Orientations

Source: Coda (2000, p. 6)

It is important to point out that within this approach the working professionals are expected to present all of these orientations during their work activities and that the differences will occur in terms of quantity and the order of preference that each one is utilized. The M.A.R.E. Diagnosis of Motivational Orientations is an instrument with sixteen affirmations with four alternatives portraying different forms of behavior in work situations related to each one of the orientations measured. So, the respondent should evaluate each alternative, giving grades as follows: score 4 for his first choice, i.e., the alternative that he most identifies with as preferred; score 3 to the second choice and successively until he attributes a score of 1 to the alternative least preferred in that situation. This procedure will produce 8 scores, one for each of the four motivational orientations (M.A.R.E.) in two different contexts which correspond to work performance under normal conditions (NC) and also under pressure (UP) conditions.

These motivational orientations are compatible to recent leadership and managerial models of behavior such as the one developed to assess leadership potential consisting also of four quadrants (DRIES; PEPERMANS, 2012): (1) Analytical skills - containing factors such 
as Intellectual curiosity, Strategic insight, Decision making, and Problem solving (equivalent to the Analytical Orientation); (2) Learning agility - containing the factors Willingness to learn, Emotional intelligence, and Adaptability (similar to the Receptive Orientation); (3) Drive - containing the factors Results Orientation, Perseverance, and Dedication (such as the Entrepreneuring Orientation); and (4) Emergent leadership - containing the factors Motivation to Lead, Self-promotion, and Stakeholder sensitivity (similar to the Mediating Orientation characteristics).

\subsection{CHARACTERIZATION OF BEHAVIORAL STYLES - BRAZILIAN MOBILIZATION STYLES - USING THE M.A.R.E DIAGNOSIS OF MOTIVATIONAL ORIENTATION}

Basing the investigation on the M.A.R.E. Diagnosis of Motivational Orientations, Ricco (2004) a doctoral thesis was presented in the Business School of University of São Paulo (FEA-USP) where seven different patterns of behavior, named Mobilization Styles emerged, representing the manners in which Brazilian managers and professionals act in work situations, thus furthering the concerns of motivational orientation manifestations. Taking advantage of the M.A.R.E. data bank, composing 4981 cases, Ricco (2004) made a comparison of the theoretical possibilities of grouping with the groupings obtained by multivariate statistical analysis and described the identified types that resulted in the seven profiles utilized in the present work.

The expression 'Mobilization Style' did not exist in any literature about Organizational Behavior and was coined to satisfy the need to name the behavioral types discovered, resulting from the M.A.R.E. Diagnosis of Motivational Orientations conceived and validated by Coda (2000). This concept refers to the intentional and particular way of operating within work organizations to achieve results and reveals the interaction between motivational orientations in normal situations (NC) and those involving performance under pressure (UP) conditions.

The statistical groupings found by Ricco (2004) were considered patterns of managerial and professional behavior, described and denominated Specialist, Collaborator, Conqueror, Maintainer, Competitor, Negotiator and Achiever. The research line - M.A.R.E. Diagnosis of Motivational Orientations - continues advancing in respect to the mapping of behavioral styles among diverse Brazilian categories of professionals and the probe into the connection between these styles and other independent variables such as productivity at work.

As an example, using Mobilization Styles as a base, Coda and Cestari (2008) investigate the links between the individual's behavioral profile and his performance in relation to a 
motivational strategy involving setting goals, variable remuneration and performance rewarded with promotions. The study, carried out using 119 retail bank managers revealed that different behavioral profiles present a significant statistical difference in relation to the fulfillment of goals established by the institution and, suggests that individuals with a Mobilization Style of conqueror present the best performance, while those with a Mobilization Style of Collaborator or Specialist present an inferior performance in relation to all other Mobilization Styles.

Miguel (2009), carrying out a study to identify the Mobilization Styles of professionals in the area of Brazilian Investor Relations (IR), revealed the Conqueror Style to be the most dominant, and Zucco (2010), who applied the M.A.R.E. Diagnosis approach to professors of business administration in graduate school at a prestigious private university in São Paulo, revealed the Negotiator and Maintainer styles as the most dominant, while Collaborator and Achiever styles were, significantly, the least expressive.

Table 2 presents a brief description of the principle behavioral characteristics of the Mobilization Styles, taken from the M.A.R.E. Diagnosis of Motivational Orientations.

\begin{tabular}{|c|c|}
\hline Mobilization Style & DESCRIPTION OF THE MAIN CHARACTERISTICS \\
\hline SPECIALIST & $\begin{array}{l}\text { Controlling and sharing valid experiences brings safety, and relationships should } \\
\text { be based on personal development as well as the proper use of others' skills. Set } \\
\text { corroborated challenges through careful actions that produce solid results as well } \\
\text { as a concern with exercising reason. Decision making based on relevant data and } \\
\text { information. Seeks to be an expert in his field of work and is guided by strategy } \\
\text { and process. Acts like a "know it all", and is persistent, careful and methodic. }\end{array}$ \\
\hline COLLABORATOR & $\begin{array}{l}\text { Gets what is considered valuable by trading with others and tends to stress } \\
\text { relationships as the only way to receive positive things and events, like success. } \\
\text { Expresses a desire to participate in teamwork as a form of personal and } \\
\text { professional self-development. Concerned with people and the quality of the } \\
\text { work process. Likes helping others and finding solutions to existing problems in } \\
\text { a participative way. }\end{array}$ \\
\hline CONQUEROR & $\begin{array}{l}\text { Credits attaining objectives to good judgment and controls what is obtained. } \\
\text { Takes possession of whatever is thought to have value. Likes competitive } \\
\text { situations that offer a chance of personal growth. Anxious to reach new levels of } \\
\text { performance and demonstrates a commitment to achieving results based on } \\
\text { processes. Seeks situations where he can present his capacity to perform and } \\
\text { achieve what is expected. }\end{array}$ \\
\hline MAINTAINER & $\begin{array}{l}\text { Most important is to assure the continuance of actions and innovations within the } \\
\text { organizational context. Establishes relationships which permit controlling and } \\
\text { overseeing situational variables while emphasizing follow-up and a concern with } \\
\text { the operational processes. Understands the beliefs and opinions of others, acting } \\
\text { responsibly, is comprehensive, methodical and persistent. Tends to avoid risks, } \\
\text { seeks security. }\end{array}$ \\
\hline COMPETITOR & $\begin{array}{l}\text { Credits having good judgment for the ability to obtain the best things in life, } \\
\text { always ready to take a chance and decide what has to be done. Seeks challenges } \\
\text { that depend on competitive performance, obstinate and resolute. Focused on } \\
\text { winning and obtaining results, using the processes that guarantee them. } \\
\text { Compares self with others when results are obtained, assumes the responsibility } \\
\text { for resolving problems. }\end{array}$ \\
\hline
\end{tabular}




\begin{tabular}{|c|l|}
\hline \multirow{2}{*}{ ACHIEVER } & $\begin{array}{l}\text { Obtaining results is what is important even if it means changing one's attitude. } \\
\text { Promotes actions aimed at achieving organizational goals and prefers to deal with } \\
\text { situations where he can make things happen. Aimed at achieving personal and } \\
\text { organizational results, is flexible, energetic and pro-active. }\end{array}$ \\
\hline NEGOTIATOR & $\begin{array}{l}\text { The important thing is to make advantageous trades protecting what has been } \\
\text { gained. Adapt to new situations or change one's opinion does not mean a loss of } \\
\text { personal influence. Promotes integration. Demonstrates a capacity to convince } \\
\text { and has considerable skill in understanding people's needs and resolving } \\
\text { conflicts. Puts self in the position of others and is focused on acquiring } \\
\text { organizational vision. }\end{array}$ \\
\hline
\end{tabular}

Table 2 - Main Characteristics of the Mobilization Styles

Source: Adapted from Ricco (2004)

\subsection{SURVEY QUESTIONS}

The theoretical context and framework presented sanction the elaboration of the research questions in this work, identified as follows.

SQ1 - Are there predominant Mobilization Style(s) among the professionals in the area of Human Resources Management (HRM)?

SQ2 - Are there differences in the predominant Mobilization Styles among the professionals in the area of Human Resources Management (HRM) who work in public organizations and those who work in private companies?

\section{METHODOLOGY}

In order to clarify how this study was carried out, characterization of the type of research, the subjects, tools used, data collection procedures, and the various steps that were performed are presented as follows.

The methodology used to develop this research has a quantitative character distinguished by the use of descriptive measures to analyze data. Due to the nature and the objectives of the question, the research is in itself exploratory since it tries to provide more familiarity with the question in the hope of making it transparent or elaborate hypothesis. The instrument employed for collecting data was the M.A.R.E. Diagnosis, made available by authorization of the author, while the Mobilization Styles were verified according to the proceedings suggested by Ricco (2004). The systematic steps executed during the research are described as follows.

\section{Step 1 Formation and analysis of the public sector sample}

The research employed the data concerning 268 professionals from the area of Human Resources Management (HRM) of the Health Department of the City of São Paulo, collected as a part of a training program on people management between 2009 and 2010 under the theme "Leadership and Motivation in the Workplace". 


\section{Step 2 Formation and analysis of the private sector sample}

The research also applied the M.A.R.E Diagnosis of Motivational Orientations questionnaire to 87 professionals in the area of HRM that exercise their work activities exclusively in private business. The methods used to collect the data were electronic mail and personal interviews. The target public of this second survey is made up of professionals from a large publishing company (Grupo Abril) and MBA students who were taking a Human Resources course at FIA - Fundação Instituto de Administração, characterizing in this way a process of sampling by convenience. The professionals that participated in this field research had their identities kept secret and received, at no personal cost, a description of the findings concerning their Mobilization Style, plus material explaining the M.A.R.E. approach and analytical instrument.

\section{Step 3 Identification of the Mobilization Styles}

According to procedures described by Ricco (2004), the values obtained for the 4 different motivational orientations evaluated were calculated using specific computer software to identify the mobilization style of each participant from the two samples collected.

\section{Step 4 General Comparative Analysis}

The Mobilization Styles of the total number of professionals sampled from the public company and private business, operating in HRM, were compared with the available national sample of Mobilization Styles of Brazilian Professionals to identify the existence of dominant styles.

\section{Step 5 Specific Comparative Analysis}

The Mobilization Styles of the professionals working in the Health Department of the City of São Paulo were compared with the professionals of HRM who work in private businesses (Abril + MBA HRM students) to identify the existence of different dominant styles between the two samples.

\section{RESULTS}

\subsection{SAMPLE CHARACTERIZATION}

The information concerning the 268 professionals in the HRM area of Public Health Department of the City of São Paulo, a direct public agency, refer solely to the respective Mobilization Styles. In regards to the 87 professionals in the area of Human Resources HRM) that operate in private businesses, basically they are represented by national and multinational 
companies from diverse fields, such as banking, industry, commerce, the internet, wholesale stores, the media, graphics, logistics and distribution, education, pharmaceuticals, construction and consulting. Of the total, $68 \%$ belong to Grupo Abril and $32 \%$ are the students and former students of MBA's in HRM at FIA. Fifty-eight percent of the professionals in the private business sample have Graduate Degrees (MBA's) or equivalents and $45 \%$ occupy middle and high managerial positions or are executives. Fifty-five percent of the professionals from Grupo Abril work in the area of processes and the other $45 \%$ in strategic areas like internal consulting, compensation, communication, organizational development and performance management. In the sample from the public organ of Human Resources, $86 \%$ were women and $14 \%$ men, while from the private companies $78 \%$ were women and $22 \%$ men, an equal concentration of women in both samples.

\subsection{BEHAVIORAL STYLES OF PROFESSIONALS IN HRM DEPARTMENTS}

Table 3 reveals the Mobilization Styles identified among the professionals of the public company. The data indicates that these professionals are mostly Negotiators, Maintainers and Collaborators, with a smaller representation of the Mobilization Styles Competitor, Achiever, Conqueror and Specialist.

Table 3 - Distribution of the Mobilization Styles in the Public Sector

(Health Department of the City of São Paulo)

\begin{tabular}{c|c|c}
\hline Mobilization style & Total & Percentage \\
\hline Collaborator & 48 & $18 \%$ \\
\hline Competitor & 16 & $9 \%$ \\
\hline Conqueror & 24 & $9 \%$ \\
\hline Specialist & 27 & $10 \%$ \\
\hline Maintainer & 57 & $21 \%$ \\
\hline Negotiator & 79 & $29 \%$ \\
\hline Achiever & 17 & $6 \%$ \\
\hline Total & 268 & $100 \%$ \\
\hline
\end{tabular}

Table 4 presents the Mobilization Styles found among the professional of private companies. The data points to Conquerors, Maintainers, Specialists and Achievers as the main Mobilization Styles, with less representation of the styles Collaborator, Competitor and Negotiator.

Table 4 - Distribution of the Mobilization Styles in the Private Sector (Grupo Abril + MBA Students)

\begin{tabular}{c|c|c}
\hline Mobilization style & Total & Percentage \\
\hline Collaborator & 2 & $2 \%$ \\
\hline Competitor & 10 & $11 \%$ \\
\hline Conqueror & 18 & $21 \%$ \\
\hline Specialist & 16 & $18 \%$ \\
\hline Maintainer & 18 & $21 \%$ \\
\hline Negotiator & 10 & $11 \%$ \\
\hline Achiever & 13 & $15 \%$ \\
\hline Total & 87 & $100 \%$ \\
\hline
\end{tabular}


Table 5 presents the composition of Mobilization Styles revealed among all professionals of HRM from both samples. The data indicates that these professionals are mostly Negotiators, Maintainers and Collaborators, with fewer representatives of the Mobilization Styles Competitor, Achiever and Conqueror.

Table 5 - Distribution of the Mobilization Styles

\begin{tabular}{c|c|c}
\multicolumn{3}{c}{ of all the HRM Professionals surveyed } \\
\hline Mobilization Style & Total & Percentage \\
\hline Collaborator & 50 & $14 \%$ \\
\hline Competitor & 26 & $7 \%$ \\
\hline Conqueror & 42 & $12 \%$ \\
\hline Specialist & 43 & $13 \%$ \\
\hline Maintainer & 75 & $21 \%$ \\
\hline Negotiator & 89 & $25 \%$ \\
\hline Achiever & 30 & $8 \%$ \\
\hline Total & 355 & $100 \%$ \\
\hline
\end{tabular}

\subsection{COMPARISON OF THE MOBILIZATION STYLES OF THE PROFESSIONALS IN} HRM WITH THE NATIONAL SAMPLE

Table 6 presents a comparison of the Mobilization Styles identified among the professionals of Human Resources (HRM) considering the total of the two samples with those of the professionals on a national scale. Although the value of the chi-square test does not reveal any significant difference between the two samples $(\mathrm{p}<0,05)$, it is possible to note that the styles of Competitor and Achiever present a smaller proportion of professionals than that verified in the national sample, while the Maintainer and Negotiator Styles present a greater proportion.

\begin{tabular}{c|c|c}
\multicolumn{2}{c}{$\begin{array}{c}\text { Table 6 - Distribution of the Mobilization Styles in the sample } \\
\text { of the HRM Professionals surveyed and in the national sample }\end{array}$} \\
\hline Mobilization Styles & Percentage HRM Professionals & Percentage National Sample \\
\hline Collaborator & $14 \%$ & $15 \%$ \\
\hline Competitor & $7 \%$ & $13 \%$ \\
\hline Conqueror & $12 \%$ & $15 \%$ \\
\hline Specialist & $13 \%$ & $15 \%$ \\
\hline Maintainer & $21 \%$ & $14 \%$ \\
\hline Negotiator & $25 \%$ & $14 \%$ \\
\hline Achiever & $8 \%$ & $14 \%$ \\
\hline Total & $100 \%$ & $100 \%$ \\
\hline
\end{tabular}

6.4 COMPARISON OF MOBILIZATION STYLES OF THE PROFESSIONALS IN THE HRM AREA OF PRIVATE COMPANIES WITH THE NATIONAL SAMPLE

Table 7 presents the distribution of Mobilization Styles identified among the professionals of HRM from private companies with those professionals on the national sample. As occurred in the previous comparison, the value of the chi-square test does not reveal any significant difference $(\mathrm{p}<0,05)$ between the two samples; the Mobilization Styles of Conqueror and Maintainer present a greater proportion of professionals in the area of HRM 
than those found in the national sample, while the Collaborator style was found to be the least frequent in relation to the national sample.

Table 7 - Distribution of the Mobilization Styles in the sample of the HRM Professionals in the private companies (Abril + MBA students) and in the national sample

\begin{tabular}{c|c|c}
\hline Mobilization Style & Percentage HRM Professionals Private Sector & Percentage National Sample \\
\hline Collaborator & $2 \%$ & $15 \%$ \\
\hline Competitor & $11 \%$ & $13 \%$ \\
\hline Conqueror & $21 \%$ & $15 \%$ \\
\hline Specialist & $18 \%$ & $15 \%$ \\
\hline Maintainer & $21 \%$ & $14 \%$ \\
\hline Negotiator & $11 \%$ & $14 \%$ \\
\hline Achiever & $15 \%$ & $14 \%$ \\
\hline Total & $100 \%$ & $100 \%$ \\
\hline
\end{tabular}

6.5 COMPARISON OF THE MOBILIZATION STYLES OF THE PROFESSIONALS IN THE AREA OF HRM OF THE PUBLIC COMPANY WITH THE NATIONAL SAMPLE

Table 8 presents the distribution of the Mobilization Styles identified among the professionals of HRM in the public company with those of the national sample. Among these professionals of HRM, the data indicates a smaller proportion of Competitor, Achiever and Conqueror styles and a greater proportion of Maintainer and Negotiator styles in relation to the national sample.

Table 8 - Distribution of Mobilization Styles of the Professionals of HRM in the Public Sector and in the National Sample

\begin{tabular}{c|c|c}
\hline Mobilization Style & Percentage HRM Professionals Public Sector & Percentage National Sample \\
\hline Collaborator & $18 \%$ & $15 \%$ \\
\hline Competitor & $6 \%$ & $13 \%$ \\
\hline Conqueror & $9 \%$ & $15 \%$ \\
\hline Specialist & $10 \%$ & $15 \%$ \\
\hline Maintainer & $21 \%$ & $14 \%$ \\
\hline Negotiator & $29 \%$ & $14 \%$ \\
\hline Achiever & $6 \%$ & $14 \%$ \\
\hline Total & $100 \%$ & $100 \%$
\end{tabular}

6.6 COMPARISON OF MOBILIZATION STYLES OF THE PROFESSIONALS IN THE AREA OF HRM BETWEEN THE PUBLIC COMPANY AND THE PRIVATE BUSINESSES

Table 9 presents the distribution of the Mobilization Styles identified among the professionals of HRM in the public company with those professionals of HRM in the private sector. The value obtained for the chi-square test indicates there are statistically significant differences in the distribution of values obtained for the two samples at a level of $p<0,001$. The data reveals there are significant differences for all styles except the Maintainer, for which both proportions are equal. In the private businesses, the proportions of Competitor, Achiever, Conqueror, and Specialist styles are greater while those of Collaborator and Negotiator are greater among professionals operating in the public organization. 
Table 9 - Mobilization Styles of the HRM Professionals in Private Businesses and the Public Organization

\begin{tabular}{c|c|c}
\hline $\begin{array}{c}\text { Mobilization } \\
\text { Style }\end{array}$ & $\begin{array}{c}\text { Percentage HRM Professionals Public } \\
\text { Sector }\end{array}$ & $\begin{array}{c}\text { Percentage HRM Professionals Private } \\
\text { Sector }\end{array}$ \\
\hline Collaborator & $18 \%$ & $2 \%$ \\
\hline Competitor & $6 \%$ & $11 \%$ \\
\hline Conqueror & $9 \%$ & $21 \%$ \\
\hline Specialist & $10 \%$ & $18 \%$ \\
\hline Maintainer & $21 \%$ & $21 \%$ \\
\hline Negotiator & $29 \%$ & $11 \%$ \\
\hline Achiever & $6 \%$ & $15 \%$ \\
\hline Total & $100 \%$ & $100 \%$
\end{tabular}

\section{CONCLUSIONS AND RECOMENDATIONS}

The HRM professional, a liaison between employees and an organization's executives , has become, as well as professionals of other functional areas, faced with a constantly changing corporate environment involving rising levels of competition and complexity. Endeavoring to meet these challenges, this professional develops specific behaviors which originate his mobilization style at work, establishing him as a member of a group of professionals with similar behavior and actions, or in other words, a group of people with their own behavioral characteristics. The present study contributes by revealing what characteristics describe the manner in which the professional acts to achieve results, and thus, satisfy his basic objectives. In this manner, the collected data regarding the 355 respondents confirm the primary question in revealing as specific Mobilization Styles characterizing professionals of HRM, the styles of Negotiator, Maintainer and Collaborator. Conversely, the least representative styles were Competitor, Achiever and Conqueror.

These results are compatible with the traditional role and operational view or approach of the HRM area and, up to a certain point, were expected as dominant styles of these professionals. Since the inception of HRM in Brazil during the 1970's, the area has been responsible for mediating between the necessities of the workforce and the real possibility of meeting those needs in the organizational environment. Therefore, reaching agreements favorable to both parts - employees and board of directors -, singular characteristic of the Negotiator style, as well as being able to give and promote continuity of the norms and policies of HRM, assignments typical of the Maintainer style, match up with what is traditionally considered an effective and ideal performance on the part of a "standard" professional in the area of HRM. The third dominant style identified, Collaborator, also fits within this context, which still considers the area of HR a supplier of help for the working employees. This help should come, whether it be from the implementation of people development and training programs or from the continued improvement of the other HRM 
policies, mainly those that value and recognize the worth of the employees such as compensation and employee recognition programs.

It must be remembered that during the initial phase of Human Resources Management in Brazil the professional of this area was not expected to assume a posture focused on generating results and creating company value. By the end of the 1990's this situation began to change drastically with the beginning of globalization and its' resulting competition, bringing with it an imposition - for the HRM professional also - to focus on and contribute effectively to obtaining organizational results.

Probably, due to the new reality, the dominant styles that focus on entrepreneurship, Achiever, Conqueror and Competitor, with behavior typically guided by obtaining that which was planned, the generation of results and productivity and a constant search for challenges in the exercise of their activities, had not yet appeared in HRM. Thus, the first question raised by the present study receives an affirmative answer since the most frequent Mobilization Styles as well as the least frequent, were identified among the professionals in the area of HRM, thus leaving to be explored the differences in the composition of these styles in relation to the type of organization in which the HRM professional exercises his functions.

Although still preliminary in character due to all it comprehends, another significant result responding to the second objective of this study touches on differences in mobilization styles found among HRM professionals in private and public organizations. As was previously noted, the proportion of Competitor, Achiever, and Conqueror and Specialist styles was greater in private businesses while the proportion of Collaborator and Negotiator styles was greater among professionals in the public organization.

Within the context of private businesses, these results appear to indicate the occurrence of two distinct facts. First, professionals in the area of HRM could have been replaced by professionals with a focus on results, having behavioral styles more compatible with the immediate, short-term necessities of an organization, that is, cope with a corporate world dominated by competition. The second possibility, more complex and challenging, is that professionals in the area of HRM have made a qualitative leap in terms of focus and performance. If so, they began operating in function of necessities of context, becoming guided by the generation of results and the search for and fulfillment of challenges, main characteristics of three dominant Mobilization Styles, Competitor, Conqueror and Achiever. 
The existence, also, of the mobilization style Specialist in private businesses indicates that in these organizations, whether it was replacement of the professional or a change in his behavior, it was not done without losing sight of the quality and technical efficiency of the processes and activities of HRM, essential concerns of professionals with the Specialist style of mobilization.

The two styles found in the public company surveyed, Negotiator and Maintainer, are responsible for the most traditional challenges facing professionals in the area of HRM, focusing on resolving conflicts between employer and employee and the gradual evolution of the policies in favor of betterments for the employees. It is also worth mentioning that in this type of organization a direct concern with results and goals is something new or has not yet become incorporated into the work agenda. The response has come in the form of attempts to install models of personnel management based on skills that promote directly or indirectly, a leveraging for the organization's intended results.

Another point of interest regarding the present work is the dialogue with the perspectives of Ulrich $(1997,2000)$ and Smilansky (1997) for performance of the HRM area. According to these authors, the new agenda for the area of HRM and its employees gives precedence to two essential points: first, promote business competitiveness, and second, if the first aspect is successful, perform a role seen as strategic within the organizational context. To do this the professionals should focus on their work production rather than specialization and the technical quality of what they do. They should combine their role in terms of its value, producing mechanisms that yield functions of HRM which cause results to flow quickly. They should develop a capacity for learning and evaluating results and the impacts of policies and proceedings which they can bring into play whenever the competitiveness of their organizations increases or is maintained, instead of giving precedence to the comfort and well-being of the employees; to sum up, they should become conscious of the fact that they have to lead the cultural transformation within the context of their work.

In respect to the operational roles and strategies to be carried out by the HRM area employees, Ulrich (1997, 2000) indicated as the main ones: (1) Strategic Partner: it means adjusting HRM strategy with business by means of diagnosis and concluding with implementation of the entrepreneurial strategy; (2) Administrative Specialist: represents the efforts to analyze and propose improvements not only of the HRM processes, but also of the organizational processes, concluding with administrative efficiency; (3) Employee Champion: features concern for and a posture of listening and responding to employee's demands, 
concluding with a commitment from employees and an improvement in their skills; (4) Change Agent: makes sure that processes which promote change are put into action and effected, concluding with the organization's capacity to change and pursue objects, goals and results. Within this referential framework, the results of field study involving the public organization reveal that the professionals of the HRM area have Mobilization Styles that are more compatible with the roles of Change Agent and Employee Champion since the dominant styles are Negotiator and Collaborator while in private businesses the dominant styles are Competitor, Achiever, Conqueror and Specialist giving support to the roles of Strategic Partner and Administrative Specialist.

In the interest of finalizing this present work, it is worthwhile to note that knowing the Mobilization Styles of professionals in HRM not only permits a better understanding of their motivations and primary behavioral characteristics, but also, of how to advise the hiring, permanence and development of these professionals. So, if the performance challenge is linked to the generation of results, it is recommended that professionals with the styles of Conqueror, Competitor and Achiever be sought out. On the other hand, if the objective is to obtain commitment, enrichment and loyalty to the company, then, the styles Collaborator and Negotiator are the most indicated.

As regards the development of these professionals in the case they are with a public company, the training programs should be focused on entrepreneurial management, establishment and derivation of departmental goals in support of organizational goals, regardless of the actual business strategy since the presence of Mobilization Styles derived from the Entrepreneuring orientation, proved to be very low. Conversely, in private businesses the development of HRM professionals should be aimed at the role of Employee Champion, in that the employees basically need to develop the Receptive motivational orientation, intensely present in the Collaborator style. Also, training programs focused on the comprehension of individual differences, diversity, ethics, interpersonal relationships and teamwork could be realized.

Therefore, the Mobilization Styles identified as dominant allow determining which roles have the greatest chance of being fulfilled, since certain styles furnish a natural base for certain roles, as for example, the Mobilization Style Negotiator is more suited to the role of Change Agent, the Maintainer style more compatible to the role of Strategic Partner, while the Collaborator Style benefits the role of Employee Champion. 
It is also worth pointing out the limitations of the present study as regards the size and purpose of the samples used in the analysis. Thus, at the present dimension of the research, generalizations that include all HRM professionals should be avoided, as this would depend on a more detailed planning of the sample, including level (local, state, regional, national, etc.), and choosing the best manner of collecting the data. Therefore, other studies are recommended utilizing larger, more representative samples with public and private organizations of various sizes and sectors to correctly evaluate, in function of more comprehensive results, the very 'strategic character' of the HRM area within organizations.

\section{REFERENCES}

BOWDITCH, J. L. Elementos de comportamento organizacional. São Paulo: Pioneira, 1992.

BULLER, F. P.; MCEVOY, G. M. Strategy, human resource management and performance: sharpening line of sight. Human Resource Management Review, v. 22, p. 43-56, 2012.

CODA, R.; CESTARI, V. R. A relação entre perfis de comportamento gerencial no trabalho e o desempenho em estratégias motivacionais voltadas para a geração de resultados: um estudo no ambiente bancário. BASE - Revista de Administração e Contabilidade da Unisinos, v. 5, p. 54-66, 2008.

CODA, R.; RICCO, M. F. F. Estilos de comportamentos de profissionais de ciência, tecnologia e informação (C, T\&I). Revista de Administração Contemporânea, v. 14, p. 516-531, 2009.

CODA, R. et al. Strategic HRM? A Study of the perceived role of HRM departments in Brazil and Peru. Brazilian Administration Review (BAR), v. 6, p. 15-33, 2009.

CODA, R. Understanding intrinsic motivation: a research among Brazilian professionals. In: ANNUAL RESEARCH CONFERENCE, 2000, Bowling Green (NC). Anais... Bowling Green: Academy of Human Resource Development, 2000. p. 1-22.

CODA, R.; FONSECA, G. F. Em busca do significado do trabalho: relato de um estudo qualitativo entre executivos. RBGN - Revista Brasileira de Gestão de Negócios, 6, 7-18, 2004.

DAVIDOFF, L. L. Introdução à psicologia. São Paulo: Makron Books, 2001.

DECI, E.; FLASTE, R. Porque fazemos o que fazemos: entendendo a automotivação. São Paulo: Negócio, 1998.

DE WINNE, S. et al. Comparing and explaining HR department effectiveness assessments: evidence from line managers and trade union representatives. International Journal of Human Resource Management, v. 24, p. 1708-1735, 2013.

DRIES, N.; PEPERMANS, R. How to identify leadership potential: development and testing of a consensus model. Human Resource Management, v. 51, p. 361-385, 2012. 
DUBOIS, C. L. Z.; DUBOIS, D. A. Strategic HRM as social design for environmental sustainability in organization. Human Resource Management, v. 51, p. 799-826, 2012.

DUTRA, J. S. Gestão de pessoas. São Paulo: Atlas, 2009.

FROMM, E. Análise do homem. Rio de Janeiro: Zahar, 1986.

GOLEMAN, D. Trabalhando com a inteligência emocional. Rio de Janeiro: Objetiva, 2004.

LENGNICK-HALL, C.; ANDRADE, L. S.; DRAKE, B. Strategic human resource management: The evolution of the field. Human Resource Management Review, v. 19, p. 64-85, 2009.

MACCOBY, M. Understanding the people you manage. Research Technology Management, v. 48, p. 58-60, 2005.

MARESCAUX, E.; WINNE, S.; DE SELS, L. HR practices and HRM outcomes: the role of basic need satisfaction. Personnel Review, 42, 4-27, 2013.

MIGUEL, L. F. Estilos comportamentais dos profissionais da área de relações com investidores. 2009. Dissertação (Mestrado) - Universidade Municipal de São Caetano do Sul (UMSCS), São Caetano (SP), Brasil, 2009.

RICCO, M. F. F. Construindo perfis de mobilização em ambiente organizacional: os estilos de mobilização dos gestores brasileiros. 2004. Tese (Doutorado) - Universidade de São Paulo (USP), São Paulo, Brasil, 2004.

ROBBINS, S. P. Comportamento organizacional. São Paulo: Pearson Prentice Hall, 2010.

SIEVERS, B. Work, death, and life itself. Berlin: Walter de Gruyter, 1994.

SMILANSKY, J. The New HRM. Boston: International Thomson Business Press, 1997.

SPECTOR, P. E. Psicologia nas organizações. São Paulo: Saraiva, 2002.

ULRICH, D. Human resource champions. Boston: Harvard Business School Press, 1997.

Recursos humanos estratégicos: novas perspectivas para os profissionais de RH.

São Paulo: Futura, 2000.

VAN BUREN III, H. J.; GREENWOOD, M.; SHEEHAN, C. Strategic human resource management and the decline of employee focus. Human Resource Management Review, V. 21, p. 209-219, 2011.

ZUCCO, A. Estilos de mobilização profissional de docentes em cursos de graduação em administração. 2010. Dissertação (Mestrado) - Universidade Municipal de São Caetano do Sul (UMSCS), São Caetano (SP), 2010. 